PLURAL, Revista do Programa de Pós-Graduação em Sociologia da USP, São Paulo, v. 16, n. 1, pp. 157-173, 2009

\title{
A Família no Processo de Construção Social do Mercado de Trabalho Livre dos Latifúndios Cafeeiros de São Carlos (1907)
}

Rogério da Palma*

Resumo: As relaçóes familiares adquiriram importância fundamental no processo de trabalho da economia cafeeira do oeste paulista durante a virada do século XIX para o século XX. Ainda não se conhecem, entretanto, estudos sistemáticos sobre como as famílias atuaram na inserção ocupacional de italianos e brasileiros negros, duas categoriais sociais que passaram por experiências distintas no período abordado. Por meio de consulta a um recenseamento municipal, o presente artigo possui como propósito a análise da configuraçáo familiar de italianos e brasileiros negros situados nos latifúndios cafeeiros de São Carlos durante o início do século XX. Com base na ideia de que os mercados são construções sociais e, consequentemente, relaçóes sociais que adquirem uma multiplicidade de formatos nos mais variados contextos, acredita-se que tal estudo possa auxiliar na compreensão da formação histórica do mercado de trabalho em questão. De acordo com as informaçóes levantadas, pode-se perceber, de forma parcial, que os italianos possuíam uma estratégia familiar mais centrada em torno do colonato, enquanto nas famílias formadas por brasileiros negros a permanência nessa ocupação parece dividir espaço com outras estratégias de trabalho.

Palavras-chave: família; mercado de trabalho; negros; italianos.

\section{The Family in the Process of Construction Social of Free Labor Market of the Coffee Plantations of São Carlos (1907)}

Abstract: Family relations have gained importance in the work process of the coffee economy of western Säo Paulo during the turn of the nineteenth century to the twentieth century. Little is known, however, systematic studies on how they acted in the occupational structure of Italian and Brazilian blacks, two categories social who had experiences different in the period covered.

\footnotetext{
* Mestrando em Sociologia pela UFSCar (Universidade Federal de São Carlos) e bolsista da Fapesp (Fundo de Amparo à Pesquisa do Estado de São Paulo).
} 
Through consultation at a municipal census, this article has as its purpose the analysis of family configuration of Italian and Blacks located in the coffee plantation of Säo Carlos during the early twentieth century. Based on the idea that markets are socially constructed and, therefore, social relations that acquire a variety of formats in several contexts, it is believed this study may help understanding the historical formation of the labor market in question. According to information gathered can be seen, partially, which the Italians had a familiar strategy more centered on the colonato, while in families formed by Brazilian blacks the permanency in this occupation seems to share space with other strategies to work.

Keywords: family; labor markets; blacks; Italians.

\section{INTRODUÇÃO}

Os latifúndios de café situados no oeste de Sáo Paulo constituíram-se como o principal destino dos europeus que adentraram no Brasil durante a virada do século XIX para o século XX. Elaborada em uma conjuntura de desmantelamento do regime servil, a política imigratória formulada por fazendeiros dessa regiáo aparece como a mais acabada tentativa de colocar um fim na crise de dominação senhorial que se instala a partir da década de 1870.

Os imigrantes trazidos apresentam-se, nesse sentido, como a máo de obra apta para a introduçáo plena do trabalho livre nas grandes lavouras, pelo menos no que se refere à percepção de maior parte dos proprietários de grandes lavouras ${ }^{\mathrm{T}}$. Para além do conteúdo propriamente racial que a imigração para Sáo Paulo carrega, percebe-se que alguns autores sugerem, de maneira implícita ou explícita, que diferenças nos arranjos familiares e na própria concepção de família podem ter influenciado nessa preferência dos latifundiários por trabalhadores estrangeiros. Em razão de o colonato - principal regime de trabalho nas fazendas cafeeiras após o fim do trabalho cativo - ter se constituído sob a base do trabalho familiar, certos estudos ressaltam a presença de configuraçôes e percepçôes familiares específicas entre as famílias que nele estavam inseridas.

Muitos desses argumentos parecem sustentados, no entanto, muito mais pela verossimilhança, já que ainda não possuímos muitos trabalhos acerca das estruturas familiares entre diferentes categorias de trabalhadores. Atualmente, é reconhecido o fato de que os processos de construção de mercados de trabalho não acompanham os caminhos estreitos da racionalização, mas são direcionados por normas sociais compartilhadas entre os diversos sujeitos sociais em interação. Assim, pretende-se, por meio de dados retirados de um recenseamento municipal realizado no ano de 1907 , traçar uma análise comparativa das configuraçôes familiares de italianos e brasileiros negros situados nas principais fazendas de São Carlos, um dos principais centros da economia cafeeira durante o início do século XX.

Acredita-se que tal análise possa trazer maiores indícios quanto à construção social do mercado de trabalho livre dentro desse contexto, na medida em que é capaz de servir como

\footnotetext{
I Nunca houve um consenso absoluto no debate público sobre as estratégias a serem adotadas quanto à substituição do trabalho escravo e à possível vinda de imigrantes. Mas, como será visto logo adiante, a visão que pregava a superioridade do trabalhador imigrante saiu como vitoriosa. Consultar Azevedo (2004).
} 
ponto de partida para se explorarem possíveis visóes distintas acerca da vida econômica entre as duas categorias sociais tratadas. Com as informaçóes levantadas, pôde-se inferir que os italianos firmaram uma estratégia familiar mais sólida em torno do regime de colonato, o que não ficou evidenciado no caso das famílias de brasileiros negros.

\section{A POLÍTICA IMIGRATÓRIA E SEUS DESDOBRAMENTOS NO MERCADO DE TRABALHO}

A política imigratória elaborada por fazendeiros paulistas durante o último quartel do século XIX teve como propósito colocar um fim nos conflitos que chegam à economia cafeeira com a perda da legitimidade do escravismo².

Segundo Célia Marinho de Azevedo (op. cit.), um dos fatores essenciais para se entender a imigração para o oeste paulista não consiste propriamente na escassez de mão de obra, causada, após I850, pelo fim do tráfico de escravos africanos3. Seu enfoque está na forma como a elite agrária paulista interpretava as açôes de cativos e libertos. Analisando discursos auferidos por parlamentares da entấo província de Sáo Paulo, a autora afirma que os grandes proprietários paulistas temiam a "onda negra" que chegava à regiāo. A grande leva de escravos de outras regióes do país fez crescer, na percepçáo de boa parte dos proprietários, a criminalidade e a insegurança.

As revoltas escravas acontecidas durante o período, somadas à difusão das teorias raciais do fim do século XIX dentro da conjuntura brasileira, contribuíram, segundo Azevedo, com o discurso de fazendeiros imigrantistas, os quais defendiam a vinda de trabalhadores estrangeiros para substituir os atuais escravos. O entendimento geral dos que defendiam a imigraçáo era de que os europeus seriam o grupo social mais adequado ao trabalho livre, uma vez que os negros não encarnavam os atributos morais propícios ao trabalho não coercitivo.

Para esses latifundiários imigrantistas, a vadiagem e a propensão à criminalidade presente entre os negros, como bem mostravam os recentes levantes, as fugas e os crimes cometidos por escravos em toda a província, tornavam-nos sujeitos naturalmente avessos à racionalidade presente no trabalho livre. O subsídio para a vinda de uma quantidade sem precedentes de imigrantes estaria atrelado, dessa forma, a uma clara política racial desejada por elites da época.

Chama a atenção o fato de que todos os projetos políticos que visavam abolir a escravidão vinculavam a implementação da "aboliçăo" à ideia da importação de mão de obra europeia (= "branca"). Baseados numa concepção já mais "naturalizada" de "negro"

\footnotetext{
2 Uma interessante discussão sobre a perda de legitimidade do escravismo está em Costa (1989).

3 A Lei Eusébio de Queiroz, que colocou um fim definitivo no tráfico negreiro, cessou a principal fonte de mão de obra utilizada na economia cafeeira de São Paulo até entáo. A solução foi a compra de escravos em regióes cujos empreendimentos não se encontravam em um momento de expansão, tais como boa parte do Nordeste, de Minas Gerais e do Rio Grande do Sul. Alguns autores, entretanto, chegam a afirmar que essa migraçáo de escravos náo deu conta de abastecer suficientemente a demanda por trabalhadores, requerida pelas fazendas de café, as quais se encontravam em um momento de profundo desenvolvimento.
} 
e "branco", os "espíritos progressistas" da época estavam convencidos de que a "mão de obra branca” seria mais produtiva que a "mão de obra negra”. Branco já não simbolizava mais exclusivamente valores morais-religiosos nem só o status de liberdade: agora a cor branca seria também projetada na ideia de progresso (Hofbauer, 2003, pp. 79-80)4.

Com os parlamentares imigrantistas impondo sua visão, consolida-se a formulação de um projeto que levaria milhôes de estrangeiros a São Paulos. Dentro dessa corrente imigratória que passa a compor o contingente de trabalhadores das lavouras cafeeiras paulistas, cabe destacar a grande presença de italianos. De I887 até I900, eles formavam a grande maioria dos trabalhadores estrangeiros que vieram para os cafezais, seguindo de perto os espanhóis e portugueses, durante o período de I900-I930 (Holloway, I984, p. 73).

A chegada massiva de italianos logo nos anos que procedem a abolição é vista, de modo geral, como um processo que redefine a posição dos ex-escravos dentro da economia cafeeira, ao criar uma suposta segregaçáo ocupacional. Segundo diversos estudos, ocorre uma forte redefinição étnico-racial no mercado de trabalho, sendo que os recém-chegados italianos ficaram incumbidos de exercer com exclusividade a principal atividade referente ao cultivo e à colheita do café, ou seja, a ocupação de colono (DEAN, I977; Holloway, op. cit.; VANGELISTA, I99i).

Esse regime de trabalho era a base do sistema produtivo das fazendas de café, após a abolição, e guarda consigo certa peculiaridade: o colono era contratado levando-se em conta a família como unidade produtiva, ou seja, o proprietário contratava sempre o trabalho de um grupo familiar inteiro, e não de um único trabalhador.

A mão de obra nacional, principalmente os negros, estaria, por sua vez, encarregada das atividades acessórias ${ }^{6}$. Essas ocupaçóes que muitos dos ex-escravos e seus descendentes vieram a ocupar seriam, em grande medida, tarefas sazonais e, ao contrário do sistema de colonato, eram remuneradas de forma individual, seja com pagamento mensal, seja com diárias?

${ }_{4} \mathrm{O}$ racismo presente na política imigratória é creditado, na maior parte das vezes, ao projeto de "embranquecimento" da nação, proposto por alguns intelectuais, políticos e fazendeiros, durante a consolidação da República. Esse debate, embora tenha carregado visóes divergentes, sobretudo quando se trata de intelectuais e fazendeiros - os primeiros estavam interessados em incentivar uma imigração voltada para a colonização, enquanto os segundos possuíam como prioridade a atração de trabalhadores -, tinha como pressuposto principal praticar uma "desafricanizaçáo" do país, admitindo que a inferioridade da populaçấo brasileira era a consequência de sua composiçâo racial. Para mais informaçōes sobre o assunto, consultar, além das obras já citadas, Ortiz (1982), Schwarcz (1995) e Seyferth (1996).

5 Estima-se que cerca de dois milhôes de estrangeiros seguiram a São Paulo até 1927, data em que se encerra a política de subsídio de imigrantes, sendo que a maioria desse contingente teve como destino inicial os cafezais do interior (ANDREWs, 2007, p. 17I).

6 Em um estudo anterior, conseguiu-se relativizar essa ideia de segregação ocupacional, demonstrando que havia, sim, famílias negras trabalhando no colonato. Nesse mesmo trabalho, entretanto, fica evidente a superioridade numérica dos imigrantes em relação aos brasileiros, no que toca ao exercício dessa ocupação. Consultar Palma (2007).

7 Entre essas tarefas tidas como subsidiárias estavam a de camarada (pessoa que cuidava de afazeres gerais, dentro dos limites da fazenda), carroceiro, podador, seleiro, etc. 


\section{OS MERCADOS ENQUANTO ESTRUTURAS SOCIAIS}

Estudos da chamada "nova" sociologia econômica ${ }^{8}$ vêm demonstrando que os fenômenos econômicos são eminentemente sociais, ou seja, estão inseridos nas estruturas social e cognitiva que informam os indivíduos (Granovetter, 2009; Di Maggio, 2003; Zelizer, I988).

As açóes econômicas não acompanham, desse modo, os caminhos concisos e diretos da racionalização; esta mesma uma construção social por excelência. $\mathrm{O}$ próprio mercado (conceito que orienta, na maioria dos casos, a própria ideia de campo econômico) não deve mais ser encarado somente como um mecanismo de formaçáo de preços, passível de ser apreendido pela aplicaçáo de atributos universais e objetivos. Ele é uma construçáo histórica, em que a subjetividade e a experiência individual dos agentes em interaçáo são de relevância fundamental para sua compreensão, ou seja, os mercados não passam de estruturas sociais.

A Sociologia Econômica tenta demonstrar que a "mão" do mercado é bem visível e materializa-se nas instituiçóes culturais e jurídicas, bem como nos valores envolvidos nas trocas mercantis (STEINER, 2006, pp. 37-38). Náo existe, nesse sentido, uma racionalidade absoluta/ abstrata, mas, sim, "limitada pelo contexto", isto é, influenciada por crenças partilhadas e por normas que surgem das relaçôes sociais como um todo.

O mercado, portanto, náo existe a priori; ele é (re)construído e (res)significado a partir de relaçóes sociais concretas e, consequentemente, históricas e contextuais (ABRAMOVAY, 2004). A noçáo de mercado remete, antes de tudo, a um tipo de relaçáo social institucionalizada, envolvendo a produção, a distribuição e o consumo de bens. Adquirindo diversas formas e conteúdos segundo a conjuntura social em que é empregado, o mercado deve ser encarado em sua pluralidade, e não como uma instituição homogênea (Zelizer, op. cit., p. 6ig). Essa forma de apreensáo dos mercados serve, por sua vez, para se pensar os mercados de trabalho, com vários estudos já apontando para a atuação de fatores como as redes sociais e as preferências étnico-raciais em sua configuraçãa".

O processo de "marginalizaçáo" dos brasileiros negros citado é, como se pôde perceber, muitas vezes creditado à "racialização" presente no projeto civilizatório empreendido pelas elites do final do século XIX. Alguns estudos, porém, sugerem que a forma como algumas categorias de trabalhadores encaravam a família, elemento-chave dentro do colonato, também fornece indícios sobre a constituição social desse mercado de trabalho.

Segundo Verena Stolcke (1982), o colonato não foi instituído simplesmente por "forças ligadas ao mercado", mas também em razão de um "familismo" presente tanto entre os fazendeiros como entre os trabalhadores, os quais necessariamente a enxergavam como um grupo coeso em torno da cooperação no trabalho.

8 Para um breve balanço dessa bibliografia, consultar Swedberg (2004).

9 A atuação das redes sociais nos mercados de trabalho foi estudada por Santos (199i) e por Charles Tilly (2007). Para um balanço geral sobre o debate teórico em torno do conceito, consultar Truzzi (2008). Sobre a questão da "racialização" nos mercados de trabalho, consultar Guimarães e Castro (1993). 
Na bibliografia sobre o tema, os italianos são sempre retratados como trabalhadores totalmente apegados ao trabalho familiar; este mesmo visto como um valor trazido da sociedade de origem e tido como algo a ser mantido na nova conjuntura (Alvim, 1986, p. 90). Certos estudos (Colbari, 1997), inclusive, chegam até a afirmar que os italianos foram os responsáveis por, a partir de sua chegada, em fins do século XIX, introduzir na cultura brasileira, via "familismo", a valorização do trabalho.

De acordo com tal interpretaçáo, os italianos teriam trazido consigo um capital cultural, em particular, sua organizaçáo familiar e sua "ética" do trabalho, que os predispuseram a se inserirem como agentes privilegiados no momento de inserção do trabalho livre.

Sobre os negros e suas relaçóes familiares, presenciamos afirmaçóes controversas. Florestan Fernandes (1978) argumenta que, como herança da escravidáo, os negros foram levados a uma situaçáo de "anomia" logo após a aboliçáo. Sem uma experiência social condizente com a valorização da família e do trabalho, os libertos tornaram-se sujeitos pouco competitivos, sobretudo se comparados aos imigrantes.

Há uma historiografia já consolidada sobre as últimas décadas da escravidão que, no entanto, contesta essas afirmaçóes de Fernandes. Tais pesquisas demonstram a importância, tanto material como simbólica, dos laços familiares na vida dos cativos, os quais formavam até mesmo grupos extensos, cujas ligaçôes se estendiam para além da família nuclear ${ }^{10}$.

George Andrews (op. cit., p. 170) escreve que os ex-escravos carregavam consigo um forte apego à família, mas não ao trabalho familiar. Para ele, muitos dos negros que vivenciaram a escravidáo náo estavam dispostos a empregar mulheres e crianças no trabalho da lavoura, com o intuito de se desvencilhar o máximo possível da antiga condiçáo de escravo. Tal percepçáo acerca do trabalho familiar teria minado as possibilidades de inserção no colonato para os negros.

Pesquisas realizadas no âmbito das lavouras de café do Vale do Paraíba também enfatizam a incompatibilidade entre o projeto de vida delimitado pela última geraçáo de escravos e as propostas de trabalho oferecidas pelos fazendeiros.

Para Castro (1997, p. 353), a última geraçấo de escravos carregava consigo uma espécie de "projeto camponês", pautado pela ideia de autonomia no trabalho e de controle de seu próprio tempo, bem como do parentesco como um dos elementos centrais em suas relaçóes.

Possuindo como referência o chamado "tempo do cativeiro", esse projeto teria, segundo a autora, delimitado as diversas estratégias de mobilidade e fixaçấo dos últimos cativos nos latifúndios cafeeiros do Vale do Paraíba durante o pós-abolição. As expectativas e os planos contidos nesse projeto, contudo, logo foram subentendidos pelas elites reformistas como uma prova cabal da não adaptabilidade dos afro-brasileiros ao trabalho livre.

O projeto alternativo de muitos dos recém-egressos do cativeiro foi, dessa maneira, estigmatizado e transformado no alicerce para o estereótipo do negro preguiçoso e avesso ao trabalho.

Io Consultar, entre outras obras, Slenes (1999) e Castro (1997). 
Castro (op. cit.) ainda ressalta as relaçóes dos familiares traçadas ainda quando escravos eram fundamentais para os libertos na decisão de deixar ou permanecer nas fazendas onde conheceram o cativeiro.

Desse modo, o trinômio - mobilidade, laços de família e autonomia - que definia a experiência de liberdade com a qual libertos anteriormente conviviam continuava a informar suas expectativas de liberdade, definindo assim o que alguns autores têm chamado de um "projeto camponês". Engendrava-se uma ética do trabalho que incidia sobre o mercado de trabalho rural em gestaçáo (Ibidem, p. 38I).

Muitos fazendeiros do Vale do Paraíba, regiấo que não presenciou grande afluxo de imigrantes após o fim definitivo do cativeiro, apostavam, segundo Castro, os laços familiares para manter antigos cativos trabalhando em suas lavouras.

Seguindo nesse mesmo ponto, uma parcela da bibliografia (HollowAY, op. cit.; STOLCKE, op. cit.) sobre a economia cafeeira do oeste paulista faz mençáo à necessidade de certos pressupostos nos arranjos das famílias que pretendiam se encarregar da tarefa de colono com sucesso.

Para se auferir rendimentos maiores, seria interessante a família possuir diversos membros, principalmente pessoas em idade para trabalhar constantemente, o que faria com que filhos casados ou então parentes não ligados ao núcleo da família (irmãos, cunhados, sobrinhos, etc.) pudessem fazer parte das unidades familiares.

Mas será que esses arranjos familiares eram realmente decisivos no momento de contratação da mão de obra para o colonato? Há estudos realizados no âmbito da Demografia Histórica (Oliveira, I985, p. 34) que apontam na direção de que o colonato não necessariamente demandava famílias com determinadas composiçōes, mas apenas acomodava esses arranjos ${ }^{\text {II }}$.

Será, então, que outras idealizaçôes dos fazendeiros sobre os grupos de trabalhadores - como as raciais - eram de maior peso na contratação e alocação da mão de obra? A configuração familiar constitui, portanto, um importante ponto de partida para se evidenciar a atuação dos laços familiares na formaçấo do mercado de trabalho livre, dentro da conjuntura dos latifúndios cafeeiros.

Uma análise comparada dos arranjos familiares encontrados entre italianos e negros, bem como da relaçáo desses arranjos com o posto de trabalho que ocupavam, pode servir como um interessante parâmetro inicial para se perceberem possíveis visões distintas quanto à vida econômica, fato que poderia ter influenciado no perfil social do mercado de trabalho em questáo.

\section{A CONFIGURAÇÃO FAMILIAR DE ITALIANOS E NEGROS}

O município de Sáo Carlos firmou-se como um dos maiores centros da economia cafeeira do oeste paulista, em fins do século XIX. A região que o compunha foi, em I895, o

II Bassanezi (I986, p. 89) ainda afirma que, para além da configuração familiar, outros fatores não ligados diretamente à questáo familiar influíam nos rendimentos das famílias colonas. 
principal destino dos trabalhadores saídos da Hospedaria do Imigrante, um ano após alcançar o segundo lugar nesse mesmo quesito ${ }^{12}$.

Pode-se afirmar, dessa maneira, que Sáo Carlos desenvolveu-se, durante o período aqui tratado, como um típico município da fronteira cafeeira do Estado de São Paulo, residindo aí sua importância para um estudo sobre a composiçáo familiar e ocupacional dos trabalhadores presentes em suas plantaçóes.

Os dados sobre os arranjos familiares de italianos e negros que residiam nas principais lavouras do município, por seu turno, foram sistematizados por meio da consulta ao recenseamento municipal de 1907. Esse documento contém um interessante levantamento sobre a populaçáo sáo-carlense, em relaçấo a outros documentos do mesmo período. Ele possui, por exemplo, números relativos à variável "cor", fato raro em listas de habitantes da época. É certo também que esse recenseamento traz uma visão estática das configuraçóes familiares, pois se refere a um "retrato" delas, sendo impossível captar sua dinâmica ao longo do tempo. Aposta-se no fato de se estudar um alto número de famílias para amenizar esses limites.

Dito isso, cabe-nos, então, analisar os dados acerca do perfil familiar dos trabalhadores pesquisados. Ao todo, conseguiu-se delimitar dezessete propriedades para estudo, as quais estão entre as maiores da regiấo. Para fins de exposição, elas foram enumeradas de acordo com a quantidade de trabalhadores que cada uma abrigava, da maior para a menor. Resolveu-se, ainda, agrupar separadamente as famílias que trabalhavam sob o regime de colonato daquelas que ocupavam as demais atividades. Como frisado anteriormente, a ocupaçáo de colono guarda consigo toda uma especificidade, por estar baseada no trabalho familiar.

As tabelas apresentadas, sob um primeiro olhar, mostram que náo havia diferença significativa entre as configuraçóes familiares dos grupos sociais analisados. Concentrando-se nas famílias italianas que trabalhavam como colonas, pode-se dizer que as famílias nucleares geralmente alcançam mais de $60 \%$ do total dessa categoria nas propriedades estudadas. No caso das famílias de ocupaçôes diversas, as quais contêm números absolutos bem menores, os solteiros adquirem destaque em algumas fazendas, já que nessas ocupaçôes há a possibilidade de contratação de trabalhadores individuais.

Quando se observam apenas as unidades familiares propriamente ditas, a família nuclear, com percentagens que variam de propriedade para propriedade, constitui a maioria em praticamente todos os latifúndios analisados. A presença de outros parentes (como no caso de irmãos de algum membro do casal ou, entấo, de alguns "enteados" ${ }^{{ }_{3}}$ ) também é considerável nas famílias italianas que exerciam a ocupação de colono. Entre estas últimas, é ainda constante a presença de filhos casados vivendo junto com os pais. Essas duas últimas conclusóes, por sua vez, não se aplicam às famílias em demais ocupaçōes, sendo os números dessas variáveis diminutos e irregulares.

I2 Sobre a ascensão e a relevância de São Carlos para a produção de café brasileiro na virada do século XIX para o século XX, consultar Truzzi (2000).

I3 Classificamos, aqui, como "enteados" as crianças que aparecem junto com algumas famílias, e não possuem o sobrenome destas. 


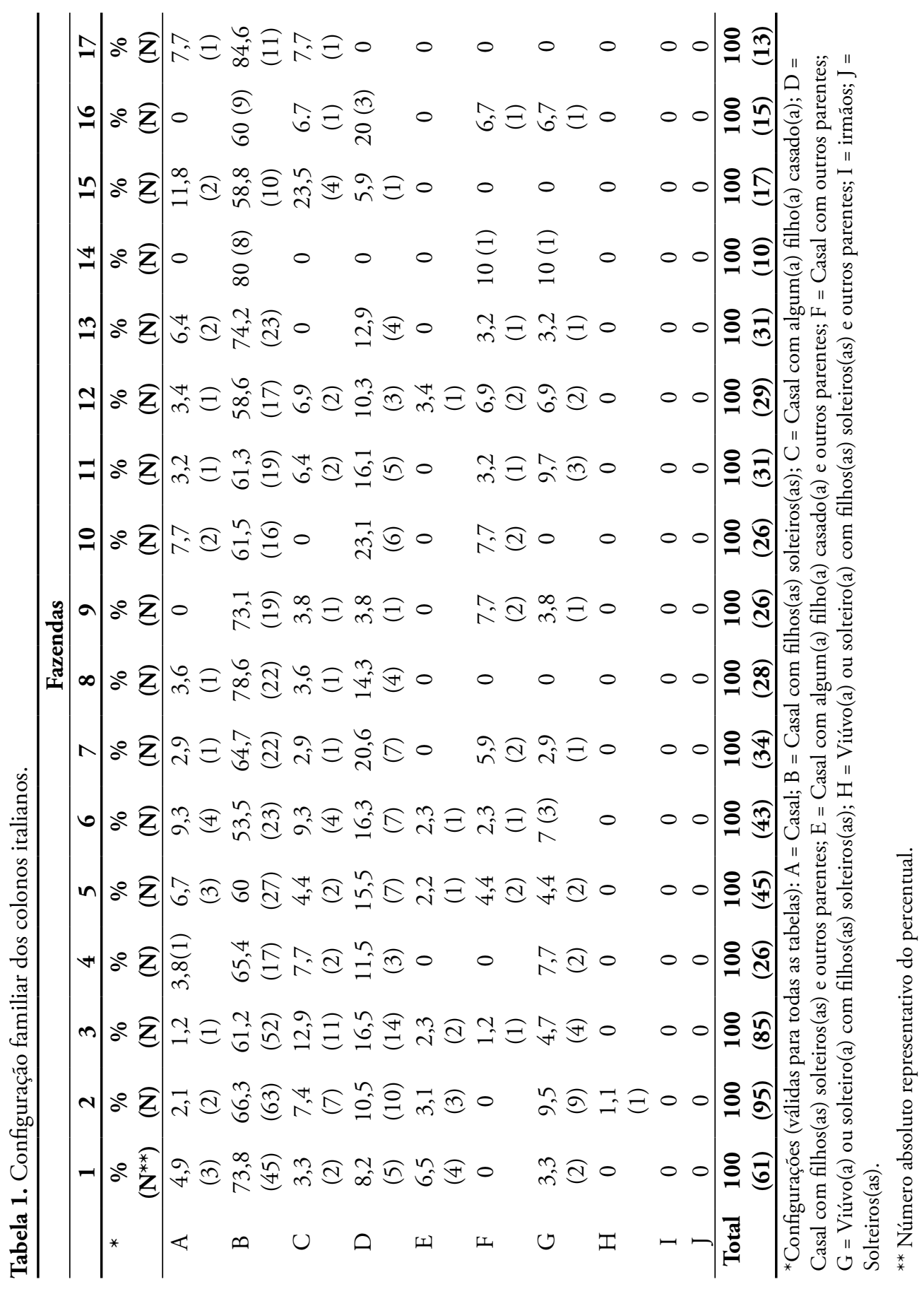




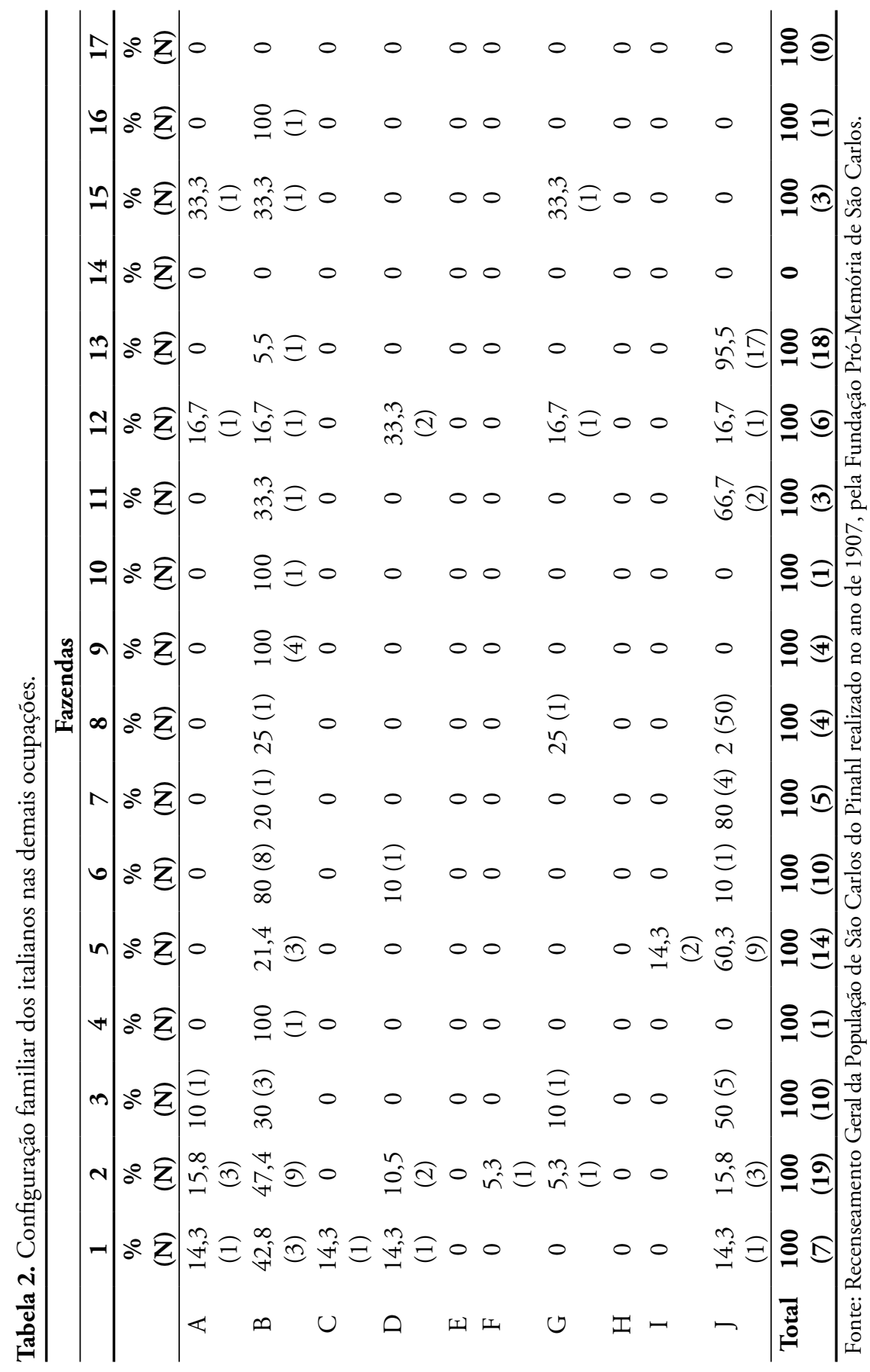

166 - plural 16.1 凹 


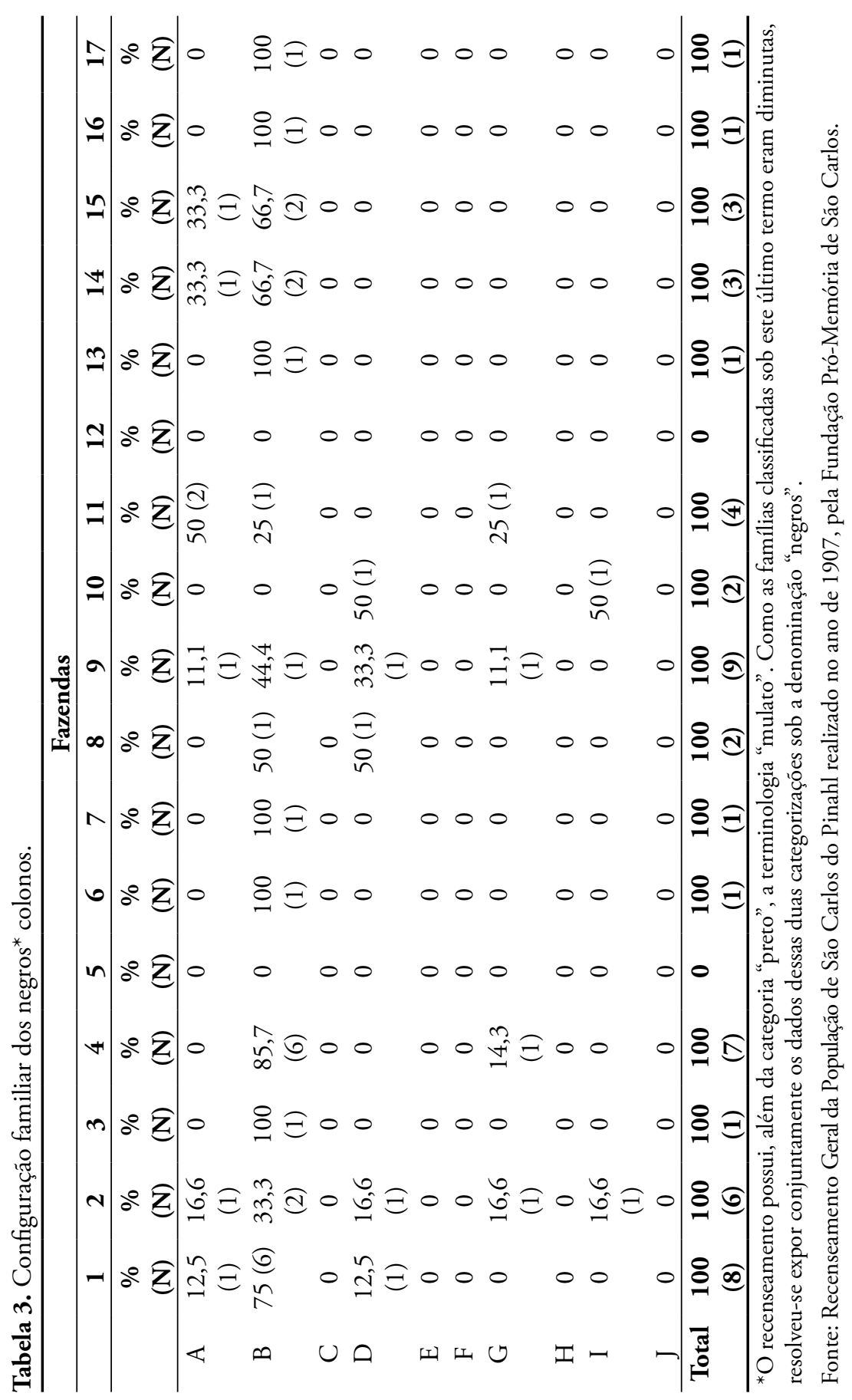

—2009 167 


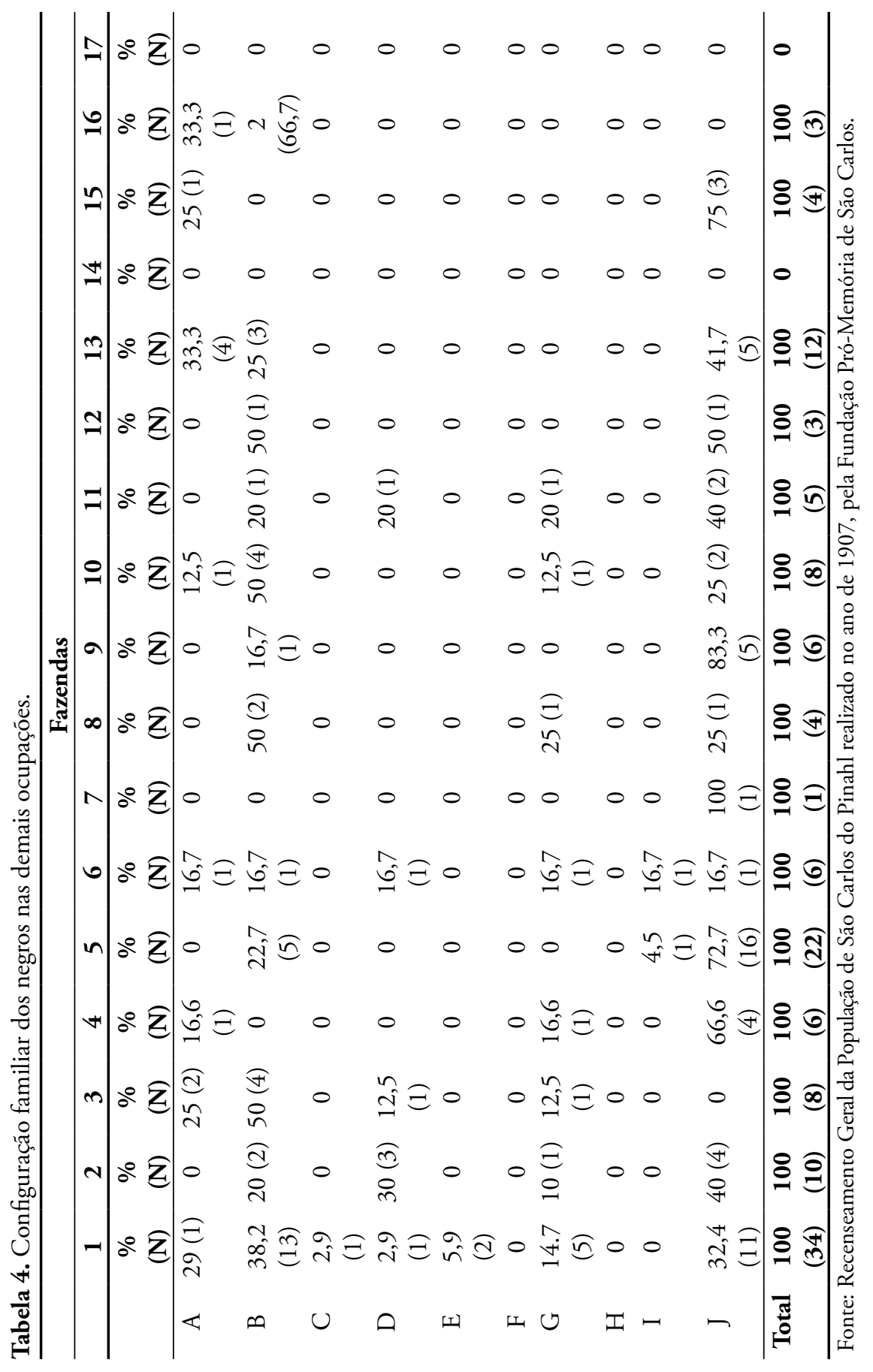


Com relação às famílias de brasileiros negros, elas, em geral, mesmo estando em números menores que os das famílias italianas, apresentam igualmente alto percentual de casais e de casais com filhos solteiros. A família nuclear, portanto, tendia a predominar também entre os negros. No que toca às famílias de negros que trabalhavam sob colonato, ainda merecem menção as que estavam com outros parentes, além dos filhos. Elas aparecem com proporçóes expressivas em algumas propriedades. A única diferença relevante na configuraçáo familiar de italianos e de brasileiros negros é a pouca presença de casais recenseados com filhos casados entre os últimos. Tal fato sugere que poderia haver menor pressão por parte de brasileiros negros para que filhos casados continuassem a fazer parte do núcleo familiar, o que poderia vir a influenciar a inserçáo ocupacional.

Exercendo maior controle sobre os filhos, os pais italianos teriam maiores possibilidades de adequar o trabalho familiar às exigências do colonato, já que poderiam contar com um número maior de indivíduos capazes de trabalhar de forma constante nas lidas da lavoura.

A interferência dos pais italianos nos relacionamentos tecidos por seus filhos é algo ressaltado na bibliografia que trata dos matrimônios envolvendo esses imigrantes. Alguns autores (MONSMA, TRUZZI, BôAS, 2005) afirmam, com base na análise de inquéritos policiais, que os pais italianos demonstravam clara preferência por conterrâneos, no que toca aos parceiros de seus filhos, por vezes, até impondo essa sua predileção.

Quando filhos de italianos se relacionavam com indivíduos de outras etnias, surgiam conflitos dentro da família, e o poder dos homens e mais velhos era colocado em jogo.

A família italiana, tantas vezes idealizada na literatura sobre imigração por sua solidariedade e devoçáo ao trabalho, também impunha seus custos, na forma de subordinaçáo das mulheres aos homens, dos jovens aos mais velhos e das vontades e dos sonhos individuais ao projeto coletivo (Monsma, Truzzi, BôAs, 2005, p. 20I).

Não é de se duvidar, portanto, que os casais italianos exerciam uma pressão maior para que os filhos que iriam se casar permanecessem compondo a máo de obra familiar e, consequentemente, permanecessem auxiliando no sonho de um dia se tornarem lavradores independentes.

Nesse sentido, os italianos, sobretudo os mais velhos (que geralmente tomavam a decisão quanto ao ato de emigrar), pareciam estar mais centrados no projeto de inserção no colonato, não admitindo que alguns de seus membros abandonassem as estratégias traçadas no âmbito doméstico. Já algumas das famílias formadas por brasileiros negros, embora possuíssem configuraçōes familiares que as capacitavam ao trabalho como colonas, não concentravam suas estratégias de trabalho de maneira exclusiva no regime de colonato.

Provavelmente, muitas delas não praticavam grandes esforços quanto à disciplinarizaçáo dos filhos no trabalho da lavoura, não colocando empecilhos quando alguns deles decidiam deixar o núcleo familiar e seguir para a economia urbana, por exemplo. 
Tudo indica que os negros presentes nos latifúndios aqui estudados, sobretudo aqueles que trabalhavam como colonos, faziam parte daquele grupo de "escravos de confiança" dos latifundiários. No oeste paulista cafeeiro, mesmo as últimas décadas de escravidáo sendo marcadas por revoltas e fugas de cativos, era comum aos fazendeiros manterem relaçôes de compadrio e de favor com alguns de seus escravos (SLENES, 1997). Essas relaçōes, por seu turno, parecem que podiam ultrapassar até mesmo o processo de abolição e da chegada em larga escala de imigrantes.

Segundo os dados agora expostos, nem mesmo os que permaneceram trabalhando como colonos nas fazendas onde antes eram cativos conseguiram (ou não preferiram) forjar uma estratégia sólida em torno da permanência de seus descendentes dentro dessa ocupação.

A ideia de estratégia familiar, que se pauta no princípio de que as relaçôes familiares podem constituir espaços importantes para se traçar planos quanto à vida econômica, parece ser útil na explicaçáo dos casos aqui analisados. Os italianos, ao auferirem de maiores poderes para persuadir seus filhos a permanecerem na mesma unidade familiar, conseguiram firmar uma estratégia familiar mais sólida no que se refere à trajetória ocupacional dentro do regime de colonato. Os brasileiros negros, em razão, sobretudo, de sua experiência social, parece que não estavam dispostos a criar estratégias consistentes, enquanto grupo familiar, em sua vida econômica; pelo menos não no que toca à execução da atividade de colono.

O conceito de estratégia familiar, por sua vez, não parte do pressuposto de que a família é um grupo coeso e fechado em si mesmo. As estratégias a serem traçadas dependem das relaçôes tecidas em outras esferas do universo social, assim como são resultado de uma negociaçáo entre os membros da família, os quais, em razão da posição que ocupam dentro da distribuição interna de "papéis", contam com recursos desiguais nessa barganha (Tilly, 1987, p. I25).

A noção de estratégia familiar ainda permite que o caso específico aqui analisado, o de formaçáo do mercado de trabalho livre dentro da economia cafeeira do oeste paulista, seja pensado como um processo que está inserido no conjunto de relaçôes sociais em que seus agentes estavam imersos.

Para finalizar, esclarece-se que as afirmações realizadas são ainda parciais e que não descartam o processo de "racialização" das relaçốes econômicas específico a esse contexto. Buscou-se somente lançar luz ao fato de que, para além de algumas generalizaçôes, há de se pensar nas estratégias com que os sujeitos concretos agem na vida econômica. O quanto as estratégias familiares aqui delimitadas podem ter sido decisivas na inserção ocupacional de italianos e negros é algo ainda difícil de se mensurar. $\mathrm{O}$ levantamento de informaçōes qualitativas, as quais tratem das visōes que italianos e negros possuíam acerca do trabalho familiar, torna-se essencial para o aprofundamento dessa questão.

\section{CONCLUSÕES}

Italianos e negros possuíam, portanto, arranjos familiares semelhantes. A única diferença significativa entre eles reduz-se ao fato de que os primeiros provavelmente exerciam maior pressão 
para que filhos casados permanecessem no mesmo grupo familiar. Tal diferença, no entanto, captada pelo conceito de estratégia familiar, sugere que os italianos que migraram para as fazendas paulistas possuíam um projeto mais bem delimitado em torno do colonato, enquanto entre os brasileiros negros havia diversas estratégias acerca da vida econômica.

A consistência de tal estratégia pode ter facilitado ainda mais a inserção privilegiada dos italianos no colonato, fazendo com que as percepçóes dos sujeitos acerca da vida econômica tenham de ser consideradas no processo histórico de formação do mercado de trabalho aqui abordado.

Aspectos qualitativos, especialmente os que tratem da forma como esses grupos encaravam o trabalho familiar, podem contribuir decisivamente para se avançar na compreensão da forma como as relaçóes familiares possivelmente atuaram na construção social do mercado de trabalho livre da economia cafeeira do oeste paulista.

\section{FONTES CONSULTADAS}

Abramovay, Ricardo. Entre Deus e o diabo: mercado e interação humana nas Ciências Sociais. Revista Tempo Social, USP, v. I6, n. 2, pp. 35-64, 2004.

Alvim, Zuleika. Brava gente! Os italianos em São Paulo. São Paulo: Brasiliense, I986.

Andrews, George R. América afro-latina, I800-2000. São Carlos: EdUFSCar, 2007.

Azevedo, Célia Maria Marinho. Onda negra, medo branco: o negro no imaginário das elites, século XIX. São Paulo: Annablume, 2004.

Bassanezi, Maria S. C. B. Família e força de trabalho: subsídios para a compreensão da dinâmica no período cafeeiro. Campinas: Nepo; Unicamp, 1986.

Castro, Hebe Mattos. "Laços de família e direitos no final da escravidão". In: Alencastro, Luiz Felipe (Org.) História da vida privada no Brasil. Império: a corte e a modernidade nacional. São Paulo: Companhia das Letras, I997.

Colbari, Antonia. Familismo e ética do trabalho: o legado dos imigrantes italianos para a cultura brasileira. Revista Brasileira de História, v. 17, n. 34, pp. 53-74, 1997.

Costa, Emília Viotti Da. Da senzala à colônia. São Paulo: Brasiliense, 1989.

Dean, Warren. Rio Claro: um sistema brasileiro de grande lavoura, I820-1920. Rio de Janeiro: Paz e Terra, 1977.

Di Maggio, Paul. "Aspectos culturais da acção e da organização econômica". In: Рeixoto, João; Marques, Rafael (Eds.) A nova sociologia econômica. Oeiras: Celta, 2003. pp. I67-194. 
Fernandes, Florestan. A integração do negro na sociedade de classes. São Paulo: Ática, I978.

Granovetter, Mark. "Ação econômica e estrutura social: o problema da imersão". In: Martes, Ana Cristina Braga (Org.) Redes e sociologia econômica. São Carlos: EdUFSCar, 2009. pp. 3I-68.

Guimarâes, Antônio Sérgio; Castro, Nadya. Desigualdades raciais nos mercados e nos locais de trabalho. Estudos Afro-Asiáticos, n. 24, pp. 23-60, 1993.

Hofbauer, Andreas. O conceito de 'raça' e o ideário do 'branqueamento' no século XIX - Bases ideológicas do racismo brasileiro. Revista Teoria \& Pesquisa, n. 42 e 43, jan.-jul. 2003.

Holloway, Thomas. Imigrantes para o café: café e sociedade em São Paulo, I886-I934. Rio de Janeiro: Paz e Terra, I984.

Monsma, Karl; Truzzi, Oswaldo; BôAs, Silvia Keller Villas. "Entre a paixão e a família: casamentos interétnicos de jovens italianos no Oeste paulista, I890-I9I4”. In: Radin, José Carlos (Org.) Cultura e identidade italiana no Brasil: algumas abordagens. Joaçaba: Editora Unoesc, 2005. pp. 177-204.

Oliveira, Maria Coleta. Questóes demográficas no período cafeeiro em São Paulo. Campinas: Nepo, Unicamp, I985.

Ortiz, Renato. Memória coletiva e sincretismo científico: as teorias raciais do século XIX. Cadernos Ceru, n. I7, 1982.

Palma, Rogério Da. O perfil étnico-racial do mercado de trabalho nos latifúndios cafeeiros de São Carlos. 2007. Monografia (Ciências Sociais) - Universidade Federal de São Carlos (UFSCar), 2007.

Recenseamento Geral da População de São Carlos do Pinhal no Ano de 1907. São Carlos: Fundação Pró-Memória, 2007.

Schwarcz, Lilia K. Moritz. O espetáculo das raças: cientistas, instituiçóes e questão racial no Brasil, ı870-1930. São Paulo: Companhia das Letras, I995.

Seyferth, Giralda. "Construindo a nação: hierarquias raciais e o papel do racismo na política de imigração e colonização". In: Maio, Marcos Chor; Ventura, Ricardo (Orgs.) Raça, ciência e sociedade. Rio de Janeiro: Fio Cruz e Centro Cultural do Banco do Brasil, 1996.

Slenes, Robert W. "Senhores e subalternos no oeste paulista”. In: Alencastro, Luiz Felipe. História da vida privada no Brasil 2. Império: a corte e a modernidade nacional. São Paulo: Companhia das letras, 1997. pp. 233-290.

- Na senzala, uma flor. Esperanças e recordaçóes na formação da família escrava - Brasil, Sudeste, Século XIX. Rio de Janeiro: Nova Fronteira, I999.

Steiner, Philippe. A Sociologia Econômica. São Paulo: Atlas, 2006. 
STOLCKe, Verena. "A família que não é sagrada. Sistema de trabalho e estrutura familiar: o caso das fazendas de café em Sáo Paulo". In: CorrêA, Mariza. Colcha de retalhos: estudos sobre a família no Brasil. São Paulo: Brasiliense, 1982.

Swedberg, Richard. Sociologia econômica: hoje e amanhã. Revista Tempo Social, USP, v. I6, n. 2, pp. 7-34, nov. 2004.

Tilly, Charles. Trust Networks in transnational migration. Sociological Forum, v. 22, n. I, March 2007.

Tilly, Louise. "Beyond family strategies, what?" In: Moch, Leslie (Org.) Family strategy: a dialogue. Historical Methods, v. 20, n. 3, 1987.

Truzzi, Oswaldo. São Carlos: café e indústria, I850-1950. São Carlos: EdUFSCar, 2000.

_____. Redes em processos migratórios. Tempo Social, Sáo Paulo, v. 20, n. I, pp. 199-218, 2008.

VAngelista, Chiara. Os braços da lavoura: imigrantes e "caipiras" na formação do mercado de trabalho paulista (I850-I930). São Paulo: Hucitec, I99I.

Zelizer, Viviana. Beyond the polemics on the market: establishing a theoretical and empirical agenda. Sociological Forum, v. 3, n. 4, pp. 614-634, I988. 